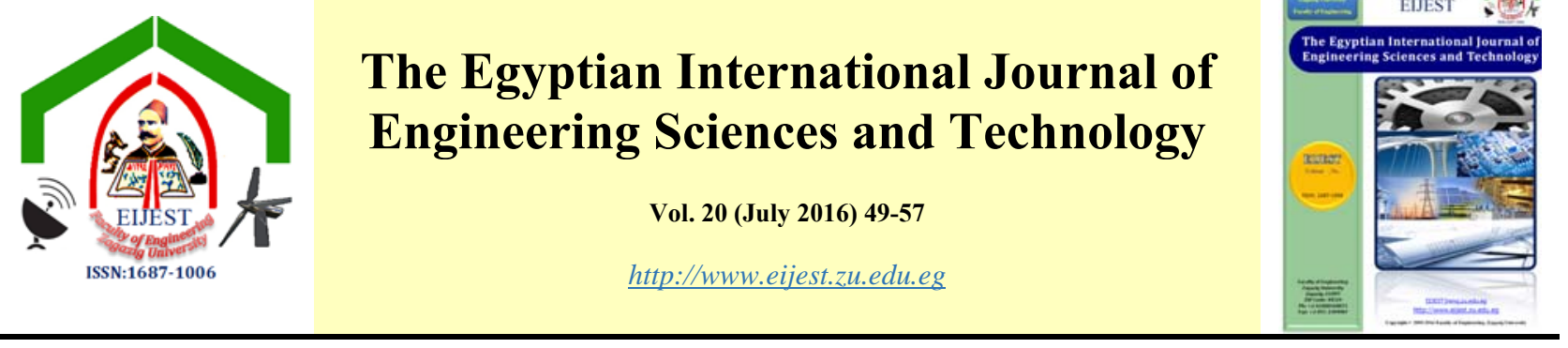

\title{
Defining the Hydraulic Dimensions and Operation Conditions for a Multi-Purpose Dam Using a 1-D Model (Case Study: Sue Dam, South Sudan)
}

\author{
A. M. Elbelasy* \\ Hydraulics Research Institute, National Water Research Centre, Delta Barrages, Egypt
}

\begin{tabular}{|c|c|}
\hline A R T I CLE I N F O & A B S T RA C T \\
\hline $\begin{array}{l}\text { Article history: } \\
\text { Received: } 5 \text { March } 2016 \\
\text { Received in revised form: } 25 \\
\text { May } 2016 \\
\text { Accepted: } 12 \text { June } 2016 \\
\text { Available online: } 14 \text { July } \\
2016\end{array}$ & $\begin{array}{l}\text { In this paper, a 1-D model; SOBEK was used for modeling the Sue River, the } \\
\text { suggested dam, reservoir and spillway. The reservoir operations of filling and } \\
\text { emptying would be simulated. The average discharge hydrograph was used for the } \\
\text { dam design. The model was used for defining the required discharges for the } \\
\text { operation of the hydropower generators, domestic use and agricultural use. The }\end{array}$ \\
\hline $\begin{array}{l}\text { Keywords: } \\
\text { Sue River } \\
\text { Dam } \\
\text { Operation Rules } \\
\text { 1-D Model SOBEK } \\
\text { Spillway } \\
\text { GIS }\end{array}$ & $\begin{array}{l}\text { manage the input and output results. The affected huts due to the rising water level } \\
\text { in the reservoir upstream of the dam were defined. The hydropower discharges, } \\
\text { dead zone \& storage volumes and hydraulic dimensions for the dam and spillway } \\
\text { were computed. The study proved that if the Sue Dam was constructed; } 40000 \\
\text { feddans would be cultivated, drinking water would be supplied to } 500,000 \\
\text { inhabitants all year round, and } 9 \mathrm{MW} \text { of electricity will be generated for the South } \\
\text { Sudan development }\end{array}$ \\
\hline
\end{tabular}

\section{Introduction}

The Republic of South Sudan became the world's newest nation in July 2011, after a peaceful referendum held in January 2011. The Republic of South Sudan is blessed with abundant water resources. However, most of these resources are unevenly distributed across the country, and are affected by wide seasonal variations. As a result of the difficult political and economic situation experienced in the country, about 75 percent of the rural population and 70 percent of the urban population of then South Sudan lacked access to safe water. Most of the existing water supply facilities were in very poor condition, and water consumption was as low as 6 liters per capita per day, representing only about 30 percent of the recommended 20 liters per capita per day. About 50 percent of existing primary schools and health centers lacked access to safe water supply and sanitation (WSS) services [1]. Moreover, South Sudan is suffering from a complete shortage of infrastructures especially electricity, roads network and telecommunications facilities. Therefore, the overall goal of the economic development strategy has been defined in Article 40 (1) of the Interim Constitution of South Sudan to be:

(a) Reduction of poverty;

* Corresponding author. 
(b) Attainment of the Millennium Development Goals;

(c) Guaranteeing the equitable distribution of wealth;

(d) Redressing imbalances of income; and

(e) Achieving a decent standard of life for the whole people

In the water sector, the main focus of the government nowadays is to start studying and developing a long term plan to establish a strategy for the best utilization of the available land and water resources. Managing water projects was determined to be one of the top priorities of this plan. Construction of Dams has been identified as a key factor for those projects. Among others, the main objectives for dam construction are:

1. Control of water resources, in addition to the development of river basins, watersheds and water catchments; so as to meet social and developmental needs of the people. For instance, seasonal flows and springs would be harnesses to overcome water shortage during the dry season or drought time.

2. Avail water for the enhancement of the productivity of the agricultural, livestock and fisheries sectors.

3. Enhance the hydropower generation potential

"EFTCA" is the Egyptian governmental instrument that coordinates official development assistance and development cooperation programs with African countries. The EFTCA is considered a part of the Egyptian Ministry of Foreign Affairs with an independent budget and has its development cooperation programs that cover most of the African continent. Since its establishment in 1980, "EFTCA" contributed effectively in building capacities and developing human resources in African countries aiming at attaining sustainable development across the continent through dispatching more than 8,500 Egyptian experts in all disciplines, like medicine, engineering, agriculture, irrigation, water resources and education, as well as affording training courses to nearly 10,000 African trainees in all fields in Egypt.

Within the Egyptian Fund for Technical Cooperation with Africa "EFTCA and financial support from the government of Egypt to the government of south Sudan, a set of development projects have been identified in consultation with the south Sudan government. One of these projects was to construct a multi-purpose dam at Sue River which has the objective to contribute to the livelihood conditions of the people of Wau city, south Sudan. A decision has been made to initiate the feasibility study of a dam construction at the Sue River beside Wau city, (Figure 1).

The suggested dam will make water available around the year especially during the dry seasons. Consequently, locals shall not need to move long distances with their livestock to search for forage and water as the dam will provide them with adequate water (both in terms of quantity and quality) for domestic use as well as for their livestock. Currently, potable water supply coverage is extremely limited and is obtained from the limited unprotected traditional sources.

After constructing the dam, a water treatment plant shall be constructed in Wau city, South Sudan, to serve about 500,000 inhabitants. The raw water shall be drawn from the Sue River after being released from the hydro power station downstream of the proposed Sue Dam. An irrigation intake shall also be implemented downstream of the dam to divert water to irrigate 40000 feddans.

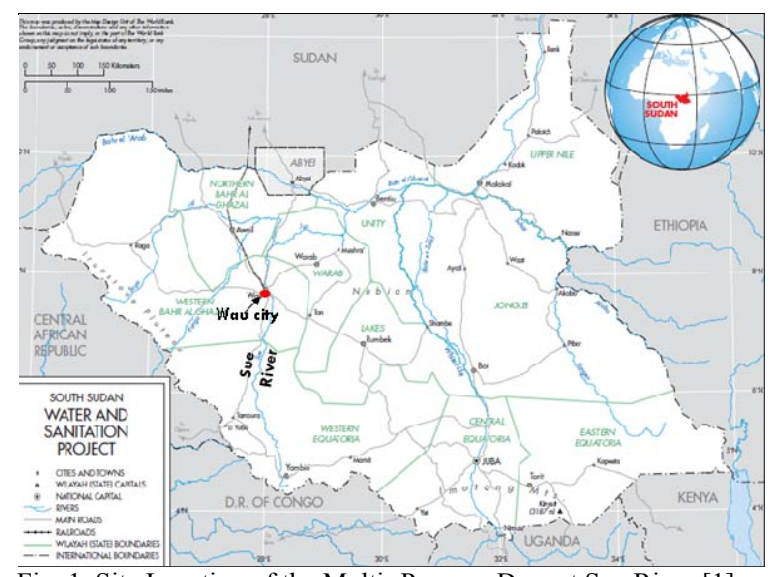

Fig. 1. Site Location of the Multi- Purpose Dam at Sue River [1]

This study was carried out using a one dimensional mathematical model named SOBEK (1D), which was used for simulating the river as 1-D, Delft Hydraulics (2009). The model simulated water flows upstream and downstream of the dam. The main goal of the simulation is defining the Hydraulic dimensions and Operation Conditions for the Multi-Purpose Dam. The detailed study objectives are:

- To determine the suitable dam crest level and the dimensions of the reservoir

- To define the capacity of the reservoir at different water levels

- To determine the daily discharges downstream of the dam and the operation rules of the reservoir (daily water levels upstream and downstream of 
the dam)

- To define the dimensions of the emergency spillway

- To define the expected urban areas that will be affected upstream of the dam.

The pre-mentioned parameters are key factors in the design of the hydropower plant, in defining the area of the irrigation scheme and designing the water treatment plant.

\section{The Study area}

The suggested dam is located at $\mathrm{km} 7$ from the confluence of the Sue and Bossery Rivers near Wau City as shown in Figure (2). This location for the dam construction was selected for structural design purposes and based on the coordination and discussion with officials of the water authorities in South Sudan. The cross section of the river at this location is smaller than other locations along the river.

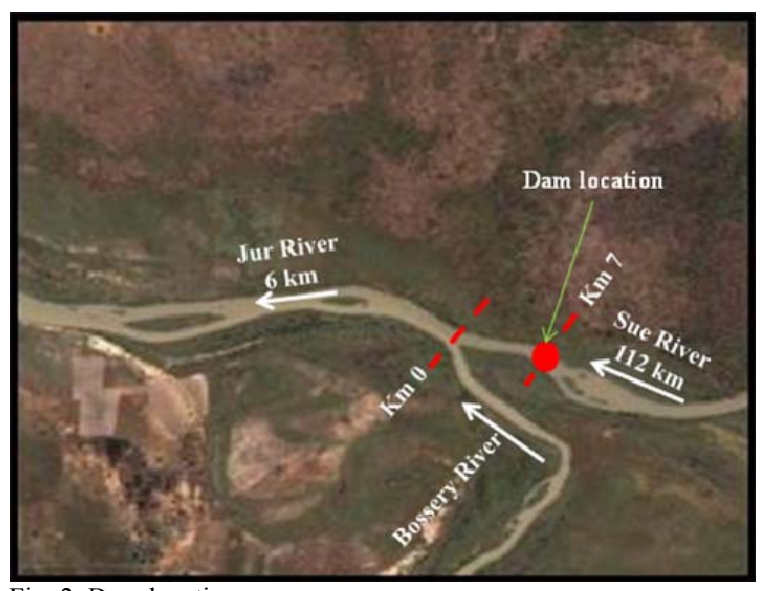

Fig. 2. Dam location

The Sue River is one of the main tributaries of the Jur River at Bahr El Ghazal Basin, South Sudan. The Jur is the most important tributary of Bahr El Ghazal. It lies in the Upper part of Bahr El Ghazal watershed between Latitudes of $8^{\circ} 30^{\prime}$ and $9^{\circ} 02^{\prime} \mathrm{N}$, and longitudes of $26^{\circ} 10^{\prime}$ and $29^{\circ} 08^{`} \mathrm{E}$. The watershed of the Jur River has an estimated area of $49000 \mathrm{Km} 2$. The altitude upstream of the dam ranges from (320) to (480) $\mathrm{m}$ above sea level. The total lengths of the Sue and the Jur Rivers is about $485 \mathrm{~km}$. The Jur is a seasonal stream. Its discharge can reach $400 \mathrm{~m} 3 / \mathrm{s}$ in September [2].

\subsection{River discharges}

The Sue River Watershed Authority provide values for the river discharges. Monthly maximum, minimum and average discharges for the Sue River are shown in Figure (3). The flow in the Sue River begins in July, the peak discharge occurs in September and decreases until December based on the available data from 1953 to 1961 . The average discharge in July is about $92.6 \mathrm{~m}^{3} / \mathrm{s}$ and the maximum is about $304.78 \mathrm{~m}^{3} / \mathrm{s}$ in September. The average discharge for the Sue River will be used for the design of the dam. The Hydropower plant, the irrigation project and the water treatment plant designs will be based on the average discharge, while the emergency spillway dimensions will be designed based on the maximum discharge.

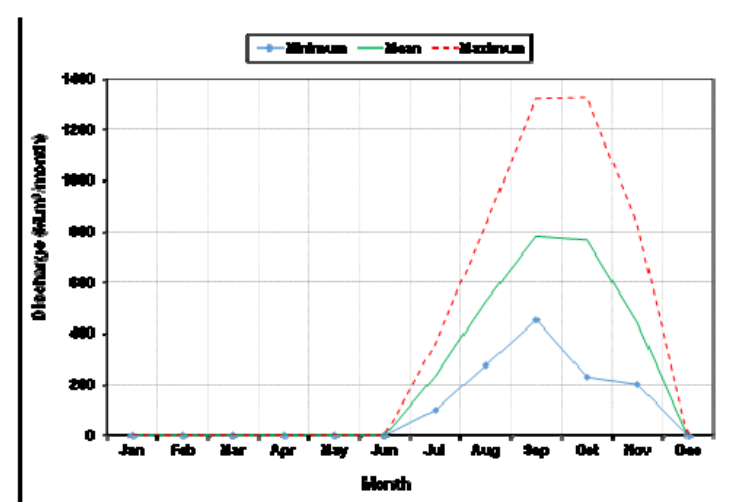

Fig. 3. Sue River, Max., Min. and Mean Discharges

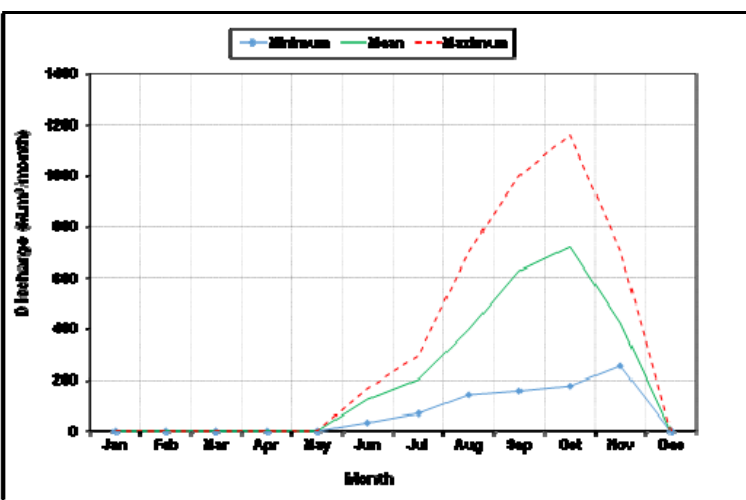

Fig. 4. Bossery River, Max., Min. and Mean Discharges.

The Bossery River shown in Figure (2) is a seasonal stream. Figure (4) shows its monthly maximum, minimum and average discharges. The flow in the River begins in June, the peak discharge occurs in October and decreases until December. The average discharge in June is about $47.67 \mathrm{~m}^{3} / \mathrm{s}$ and the maximum is about $278.46 \mathrm{~m}^{3} / \mathrm{s}$ in October. Bossery River outlet meet with Sue River outlet at $\mathrm{km} 0.0$ at Waw city as shown in Figure (2).

\section{Methodology}

This study was carried out using a one 
dimensional mathematical model named SOBEKRural. SOBEK-Rural is a powerful modelling suite for flood forecasting, optimization of drainage systems, control of irrigation systems, river morphology, salt intrusion and surface water quality. The programmes within the SOBEK modelling suite simulate the complex flows and the water related processes in almost any system. The programmes represent phenomena and physical processes in an accurate way in one-dimensional (1D) network systems and on two-dimensional (2D) horizontal grids. It is the ideal tool for guiding the designer in making optimum use of resources. Many large projects were modeled using SOBEK, [3], [4], [5], [6], [7], [8] and [9].

This model could quickly, easily and accurately simulate the flow in simple or complex channel networks consisting of thousands of reaches, cross sections and hydraulic structures. The modeler is responsible for defining all types of boundary conditions, and lateral inflows and outflows using time series or standard formulae.

For the Sue River simulations, the Flow Module has been used which is capable of simulating fully unsteady flow.

The flow module in SOBEK that is used for Regular River applications could be described by the full Saint-Venant equations for unsteady open channel flow, shown in equations (1) to (4), [10].

The continuity equation (representing the conservation of mass):

$\frac{\partial A_{t}}{\partial t}+\frac{\partial Q}{\partial x}=q_{\text {lat }}$

The momentum equation (representing the conservation of momentum):

$\frac{\partial Q}{\partial t}+\frac{\partial}{\partial x}\left(\alpha_{B} \frac{Q^{2}}{A_{f}}\right)+g A_{f} \frac{\partial h}{\partial x}+\frac{g Q|Q|}{C^{2} R A_{f}}=0$

With:

$\mathrm{A}_{\mathrm{f}} \quad=$ conveying cross-section [m2]

$\mathrm{A}_{\mathrm{t}}=$ total cross-sectional area [m2]

$\mathrm{C}=$ Chézy coefficient $[\mathrm{m} 1 / 2 / \mathrm{s}]$

$\mathrm{g}=$ gravitation constant $[\mathrm{m} / \mathrm{s} 2]$

$\mathrm{h} \quad=$ water level relative to reference level [m]

$\mathrm{q}_{\text {lat }} \quad=$ lateral inflow per unit length $[\mathrm{m} 3 / \mathrm{m} / \mathrm{s}]$

$\mathrm{Q}=$ discharge $[\mathrm{m} 3 / \mathrm{s}]$

$\mathrm{R}=$ hydraulic radius (roughly equal to the water depth) [m]

$\mathrm{t}=$ time $[\mathrm{s}]$

$\mathrm{W}_{\mathrm{f}} \quad=$ width of conveying cross-section at water surface $[\mathrm{m}]$

$\mathrm{x} \quad=$ distance along the channel $[\mathrm{m}]$

$$
\alpha_{\mathrm{B}} \quad=\text { Boussinesq coefficient }[-]
$$

The Boussinesq coefficient is a correction factor in the convective acceleration term in equation (2), to account for the non-uniform velocity distribution in the cross-section. It is computed from:

$$
\alpha_{B}=\frac{\sum_{i=1}^{n} C_{i}^{2} R_{i} A_{f i}}{C^{2} R A_{f}} \text { and : } C^{2} R=\left(\frac{\sum_{i=1}^{n} C_{i} A_{f i} \sqrt{R_{i}}}{A_{f}}\right)^{2}
$$

where:

$\mathrm{i}=$ index indicating type of sub-section in conveying cross-section $(\mathrm{i} \leq 3)$

The last expression $\mathrm{C}^{2} \mathrm{R}$ in equation (3) is also used in the bed-friction term in equation (2). The Chézy coefficient $\mathrm{C}$ is computed as a function of Manning's roughness coefficient $\mathrm{n}_{\mathrm{m}}$ :

$C=\frac{R^{1 / 6}}{n_{m}}$

For the Sue River model, the Manning's roughness coefficient provides a good representation of the hydraulic roughness for a wide range of discharges

\subsection{The Modeled Area}

The study area covers $112.00 \mathrm{~km}$ of the Sue River and $6.00 \mathrm{~km}$ of the Jur River. The dam was suggested to be at $\mathrm{km} 7.00$ from the Sue estuary near Wau City, the modeled area is presented in Figure (5). The area is relatively flat with floodplain levels ranging between (415) $\mathrm{m}$ and (500) $\mathrm{m}$ above the mean sea level and the bed levels of the Sue River range from (418) $\mathrm{m}$ to (470) $\mathrm{m}$.

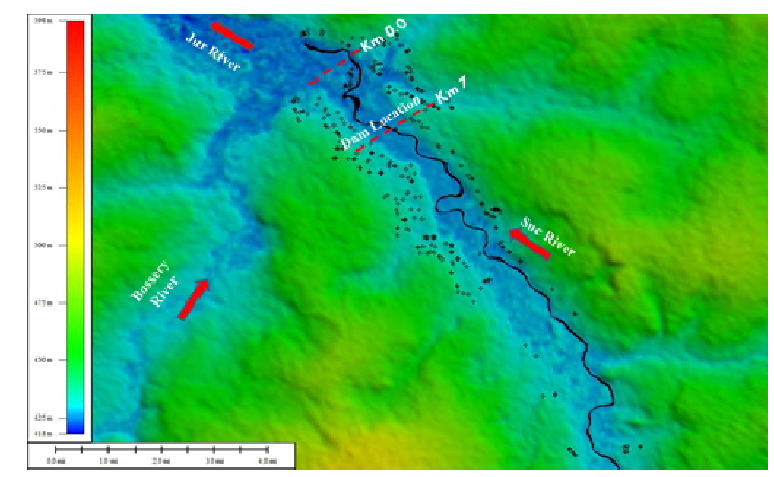

Fig. 5. The study area

\subsection{Model Construction}

During constructing the model, several elements were considered including cross sections, lateral intakes, suggested dam, hydropower plant and 
spillway, evaporation, flood discharge and the boundary conditions. These elements are discussed below:

The Cross Sections were simulated using the bathymetric survey carried out on 2008, [11]. The survey covered a $32 \mathrm{~km}$ of the Sue River and 5.5 of the Jur River. Missing cross sections were estimated using GIS and topographic maps [12].

As for the cross sections, the following was considered:

- The Sue River and the flood plain were simulated using the bathymetric survey. The cross-section data of the 10/2008 survey was used [11].

- The survey covered a length of $32 \mathrm{~km}$ of the Sue River and $5.5 \mathrm{~km}$ of the Jur River.

- Missing other cross sections along the Sue River were estimated using GIS and topographic Maps [12].

\section{Dam and Spillway}

- The dam and spillway are simulated as weirs.

\section{Hydropower}

- The hydropower is simulated as an intake, it takes its discharge from the upstream and its outlet is located at the downstream of the dam

\section{Lateral intakes}

The inflow of the Bossery River and other sources were specified as a function of time. These values must be positive in the case of intakes. The lateral discharges were specified as point discharges $\left(\mathrm{m}^{3} / \mathrm{s}\right)$. The Bossery discharges are shown in Figure (4), the main nodes are shown in Figure (6)

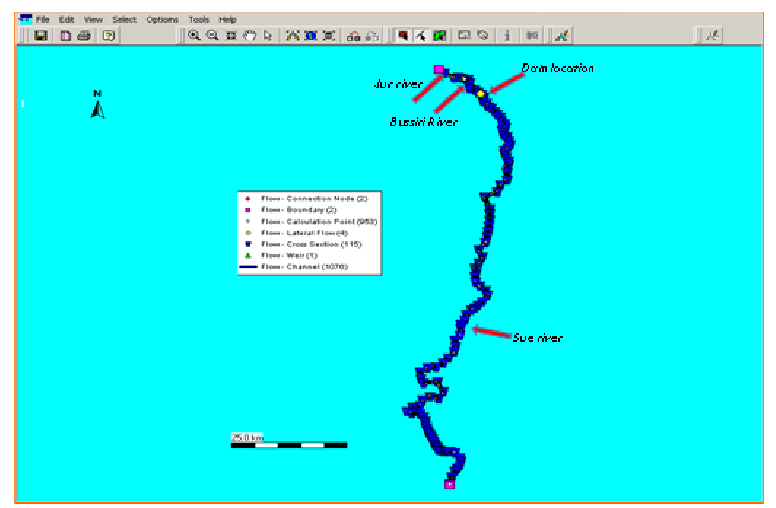

Fig. 6. Layout of the SOBEK 1-D Model

\section{Evaporation}

Evaporation was specified as an outflow and was expressed as an off-take, depending on the area of the reservoir that stores the water. This area is a function of water level in this lake. Figure (7) shows the relationship between the areas of the formed reservoir with its water level.

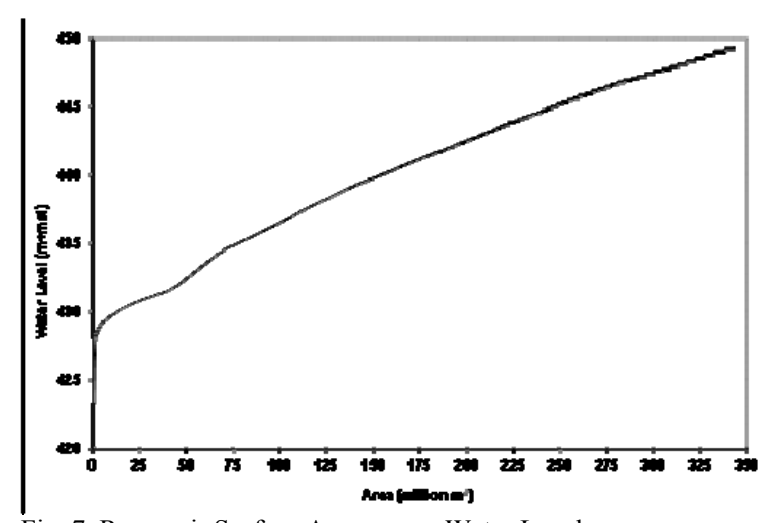

Fig. 7. Reservoir Surface Area versus Water Level

\subsection{Boundary conditions}

Boundary conditions are needed to solve the basic equations for unsteady flow. In this study, there are two boundary conditions; upstream and downstream boundaries as specified below:

\section{Upstream Boundary Condition}

The average discharge of the Sue River is considered as the upstream boundary. The discharges of the Sue River were imported from the hydrological data of the Sue River. The net discharges for the Sue River was defined using the data in Figure (3).

\section{Downstream Boundary Condition}

For the downstream boundary, water levels in the Jur River are defined based on the Jur River- Wau station and the used data is shown in Table (1). Levels in Table (1) are calculated based on the discharges of the hydropower plant and The Bossery River.

\begin{tabular}{llll}
\multicolumn{3}{c}{ Table 1. Estimated Water level (Downstream boundary) } \\
\hline Date & Water Levels & Date & Water Levels \\
& $(\mathrm{m})$ & & $(\mathrm{m})$ \\
\hline Jun. & 423.69 & Dec. & 423.18 \\
Jul. & 423.93 & Jan. & 423.18 \\
Aug. & 424.50 & Feb. & 423.18 \\
Sep. & 425.04 & Mar. & 423.18 \\
Oct. & 425.25 & Apr. & 423.18 \\
Nov. & 424.55 & May. & 423.18 \\
\hline
\end{tabular}




\section{Results and Discussion}

\subsection{Model Calibration}

The calibration of the model of the Sue River was performed based on actual measurements of inflow discharges, and water levels. The measurements were executed during the high discharge period [10], the measured discharge for Sue River is $233 \mathrm{~m}^{3} / \mathrm{s}$. The Manning's roughness values, obtained during the calibration, were applied in the SOBEK model. The calibration results of the Sue River are shown in Figure (8). From this Figure, it could be concluded that the model could provide accurate results. The differences between the measured and computed water levels were $\leq 0.08 \mathrm{~m}$.

\subsection{Model Runs}

The model was run using the dry condition for 5 years. The reservoir was empty at the beginning of the first flood. The bed level upstream of the dam is about (425.0) $\mathrm{m}$. The following parameters were assumed during the dam operation:

- The Crest level of the spillway was assumed to be $446.5 \mathrm{~m}$,

- The water discharge data summarized in Figures (3) and (4) were used,

The model was run many times by changing the discharge of the hydropower until it reached constant maximum and minimum water levels upstream of the reservoir

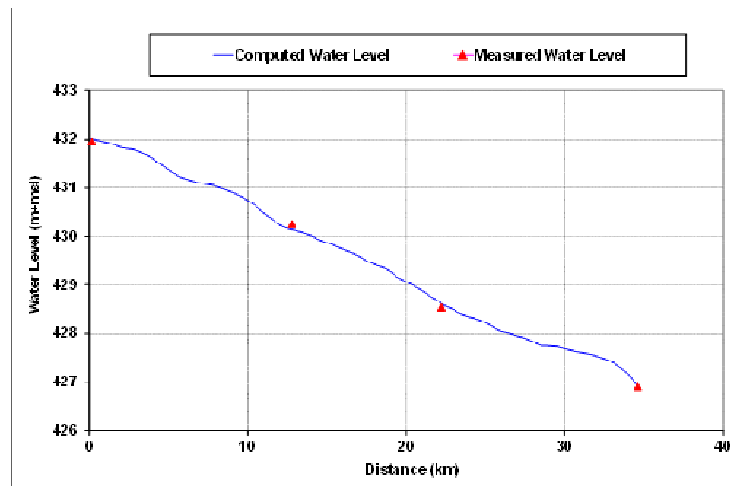

Fig. 8. Comparison between Measured and Computed Water Levels

\subsection{Model Results}

The most daily important results from the model which are very useful for the hydropower design are the discharges from the reservoir, the water levels upstream and downstream of the reservoir and the volume of the reservoir. These results are illustrated below

\section{Discharge of the Hydropower}

The model results showed that the daily average discharge from the reservoir through the hydropower is $62 \mathrm{~m}^{3} / \mathrm{s}$. Discharges that are higher or lower than this discharge makes the maximum and minimum water levels change every year, while the discharge of $62 \mathrm{~m}^{3} / \mathrm{s}$ makes the maximum and minimum values for water levels constant for consecutive floods as shown in Figure (9). The discharge of the hydropower which was taken to be $62 \mathrm{~m}^{3} / \mathrm{s}$ is higher than the drinking and irrigation water requirements, and at the same time keeps enough upstream water level to operate the hydropower plant all over the year. The required discharge to cultivate 40000 faddens is about $30 \mathrm{~m}^{3} / \mathrm{s}$, [13]. The required discharge for the water drinking treatment plant is $8.75 \mathrm{~m}^{3} / \mathrm{s}$, [14].

\section{Water Levels Upstream and Downstream of the Dam}

The results of the model showed that the maximum water level in the reservoir reached to level $445.10 \mathrm{~m}$ at the first year and $445.50 \mathrm{~m}$ for the other years. The minimum upstream water level is (435.97) $\mathrm{m}$ in the first years and $436.05 \mathrm{~m}$ in the next years. Figure (9) shows the upstream water level during the simulated period. Figure (10) shows the relationship between the water level and time, downstream of the dam. From the Figure, it can be seen that the downstream water level changes with time due to the change in the Bossery River discharges. Water levels range from (425.61) $\mathrm{m}$ to (426.67) m.

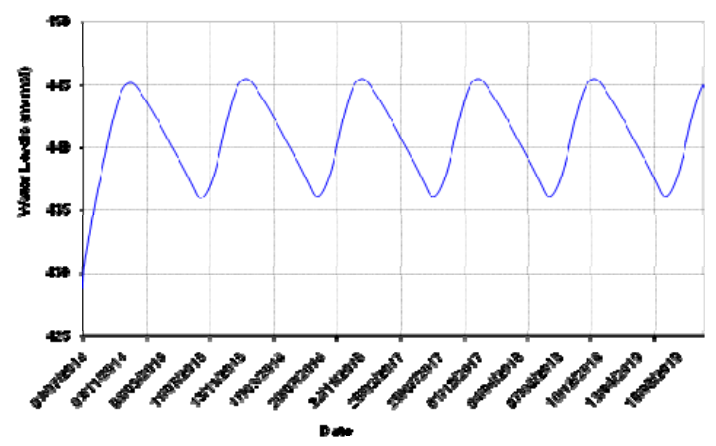

Fig. 9. Water Levels upstream The Dam for The Simulated Period 5 Years 


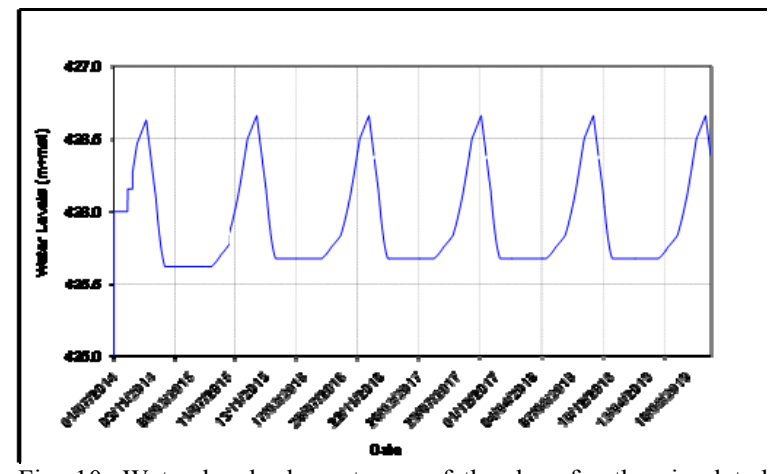

Fig. 10: Water levels downstream of the dam for the simulated period of 5 years

The relationship between time and the head difference upstream and downstream of the dam during the simulated period is shown in Figure (11). The maximum head difference is about $19.62 \mathrm{~m}$ while the minimum head difference is about $10.00 \mathrm{~m}$ as seen in Figure (11). These differences are enough to operate the electric power plant.

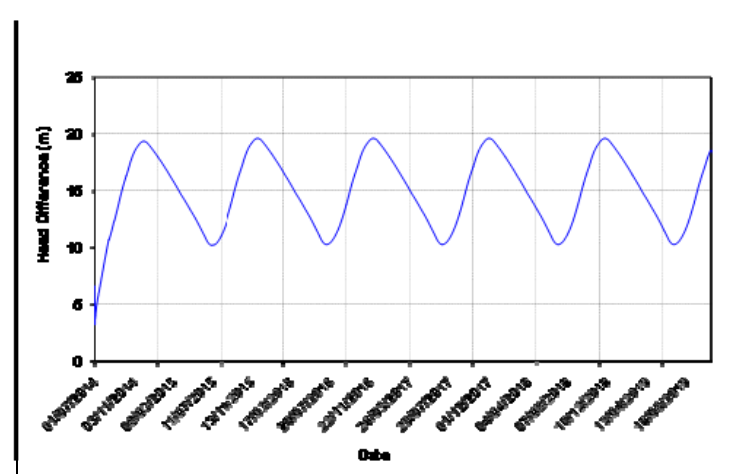

Fig. 11. Head Difference U/S and D/S of the dam for the simulated period of 5 years

\section{Emergency Spillway}

The model was also used to design the suitable length of the emergency spillway. Different lengths for the spillway that vary from $100.0 \mathrm{~m}$ to $250.0 \mathrm{~m}$ at a crest level of (446.50) $\mathrm{m}$ were tested by the model during maximum flood for a return period of 200 years. Table (2) shows the discharges of the maximum flood for a return period of 200 years. The results of the model showed that the maximum water level upstream of the spillway reached (448.5) $\mathrm{m}$ for the spillway with length of $100.0 \mathrm{~m}$ which is very close to the crest level of the dam (which is $449 \mathrm{~m}$ ) while the maximum water level upstream of the spillway reached (447.59) $\mathrm{m}$ for the spillway with a length of $250 \mathrm{~m}$. Table (3) presents maximum water levels upstream of the dam for different lengths for spillway, the selected length of the spillway will be $200 \mathrm{~m}$, maximum emergency water level upstream of the dam will be (447.78) $\mathrm{m}$.
Table 2. Discharge of Maximum Flood for a Return Period of 200

\begin{tabular}{llll}
\hline \multicolumn{3}{c}{ Years } \\
\hline Date & $\begin{array}{l}\text { Discharge } \\
\left(\mathrm{m}^{3} / \mathrm{s}\right)\end{array}$ & Date & $\begin{array}{l}\text { Discharge } \\
\left(\mathrm{m}^{3} / \mathrm{s}\right)\end{array}$ \\
\hline Jun. & 0 & Dec. & 0 \\
Jul. & 192.90 & Jan. & 0 \\
Aug. & 345.29 & Feb. & 0 \\
Sep. & 632.72 & Mar. & 0 \\
Oct. & 671.30 & Apr. & 0 \\
Nov. & 380.02 & May. & 0 \\
\hline
\end{tabular}

Table 3. Maximum Water Levels for Different Lengths of the Spillway

\begin{tabular}{ll}
\hline Spillway Length $(\mathrm{m})$ & Max. Water Level $(\mathrm{m}+\mathrm{msl})$ \\
\hline 100 & 448.50 \\
150 & 448.04 \\
200 & 447.78 \\
250 & 447.60 \\
\hline
\end{tabular}

Volume of the Reservoir

The relationship between the volumes of the reservoir and the water levels upstream of the dam was computed and presented in Figure (12). It could be noticed that the maximum capacity of the reservoir reaches 2.00 Billion cubic meters at water level of (445.50) $\mathrm{m}$.

Figure (13), shows the operational levels of the Sue reservoir. The volume of the reservoir is about 375 million $\mathrm{m}^{3}$ at the minimum operational level (436.05) $\mathrm{m}$, while reaches to 2000 million $\mathrm{m}^{3}$ at maximum operational level $(445.50) \mathrm{m}$. The dead zone volume will be 375 million $\mathrm{m}^{3}$ while the operating volume will be 1625 million $\mathrm{m}^{3}$ as shown in Figure (13). The crest level of the emergency spillway is (446.50) $\mathrm{m}$ and the maximum emergency water level is $(447.78) \mathrm{m}$.

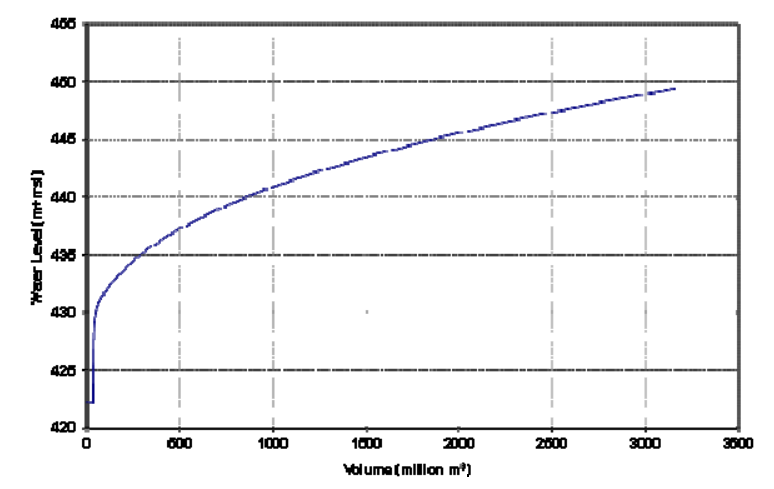

Fig. 12. Relationship between Reservoir Volumes and Water Levels Upstream of the Suggested Dam 


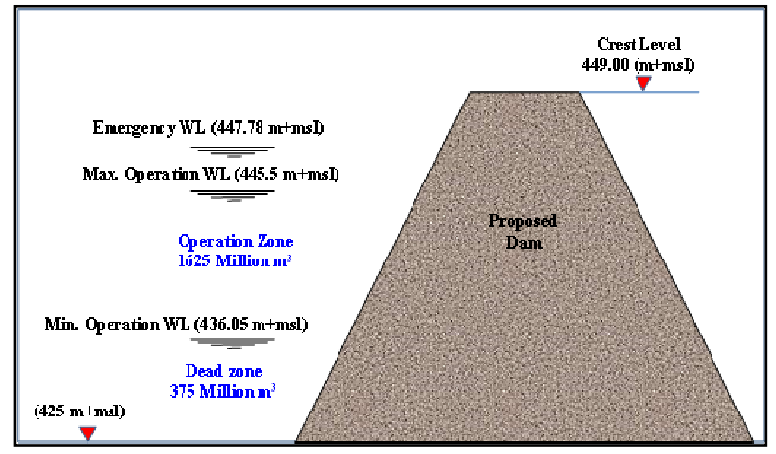

Fig. 13. Levels Upstream of the Suggested Dam, and the Storage Volume

\section{Location of Inundated Land}

The water levels that were extracted from the model output were used in GIS to identify the location of the houses and structures within the study area that were inundated due to the increasing of the water levels upstream of the suggested dam. A digital elevation model (DEM) with $90 \mathrm{~m}$ resolution was calibrated using the available surveyed elevation data which was collected during the survey mission conducted by the HRI surveying team. The calibrated DEM was then used to extract profiles along the river path. The inundated areas at different water levels; (445.5), (446.5) and (447.5) $\mathrm{m}$ were defined, consequently. The location of the expected threatened huts due to the dam construction at water levels of (445.5) $\mathrm{m}$, (446.) and (447.5) $\mathrm{m}$ were defined using UTM coordinates. An example of the inundated huts is shown in Table (4).

Table 4. An example of The Inundation Huts due to Location of dam Construction

\begin{tabular}{lll}
\hline Hut No. & X-Coordinate & Y-Coordinate \\
\hline 457 & 619149.07 & 842319.22 \\
458 & 622029.74 & 843223.84 \\
459 & 619114.68 & 843202.14 \\
460 & 619147.23 & 843094.83 \\
461 & 618830.12 & 843727.84 \\
462 & 618284.33 & 844515.59 \\
463 & 618308.04 & 844520.41 \\
464 & 618067.97 & 849139.16 \\
465 & 619825.09 & 841711.31 \\
\hline
\end{tabular}

\section{Conclusions}

Based on the Sue River investigations, in South Sudan, and the results of the hydrographic survey, a 1-D mathematical model for the river and dam was developed by using SOBEK 1-D model. The model provided a hydraulic design of the dam and defined the rules of the reservoir operation.

The study proved that the Sue Dam would be able to provide enough water on yearly basis to provide an area of 40,000 acres with irrigation system and drinking water for about 500,000 inhabitants. The dam will also have electricity generation of $9 \mathrm{MW}$.

These results, obtained from the model simulation are very important for carrying out the feasibility study including the social, economic and environmental aspects.

\section{References}

[1] WL, 2013, "Implementation Completion and Results Report (TF-96197) for Water Supply and Sanitation Project, South Sudan" Report No: ICR00002560, World Bank, 2013.

[2] Hughes, R.H.; J.S. Hughes (1992), "A Directory of African Wetlands". The World Conservation Union (IUCN). p. 233. ISBN 2-88032-949-3

[3] Sloff, C.J., Ogink H.J.M. \& Janssen, A.P.A.M. (2004), "SOBEK-Nile Schematisation, Calibration and Verification". Technical Report, Workpackage 1.6. WL|Delft Hydraulics Report Q3181.

[4] Klass-jan V. H., A. Verwey and Melger E. (2002), "Dutch Approach to High Speed Urban Drainage Modelling with SOBEK", 9th International Conference on Urban Storm Drainage, September 8-13, Portland, USA.

[5] Delft Hydraulics (2001), "Sistan Flood Warning and Emergency Plan Preliminary Hydraulics Modelling Report" WL|DELFT HYDRAULICS, Delft, the Netherlands.

[6] Stelling, G.S., Kernkamp, H.W.J. \& Laguzzi, and M.M. (1998) Delft Flooding System: a powerful tool for inundation assessment based upon a positive flow simulation. Hydro informatics '98, eds. Babovic and Larsen, Balkema: Rotterdam, pp. 449-456, 1998.

[7] Hassan S. (2010), "Analysis of Hydraulic Hazards of Inundation of Delta Lands due to Delta Barrages Failure" M.Sc. Thesis, Irrigation and Hydraulic Department, Cairo University, Egypt.

[8] A. M. EL-Belasy (2004), "Study of the Discharge Capacity of the Damietta Branch for High Flows", Hydraulics Research Institute (HRI), Delta Barrage, Egypt, Technical Report No. 108/2004.

[9] A. M. EL-Belasy (2006), "The Effect of Spits Formation at River Mouths on the Nile Delta Inundation", International Sediment Initiative Conference (ISIC), Khartoum, Sudan, November 12-15, 2006.

[10] Delft Hydraulics (2009), "SOBEK Manual Help", Technical Reference Manual, Delft, IHE, Delft, the Netherlands.

[11] Amin A. M. and Abd El-Basset K. (2014, 265), "Hydrographic Survey - Sue River Studies, Wau, South Sudan", Hydraulics Research Institute (HRI), Delta Barrage, Egypt, Technical Report No. 265/2014

[12] Amin A. M, Fahmy S. Abdelhaleem and Abd El-Basset K (2012), "Application of Data Collection Technologies in River Catchments (Case study: Sue River, South Sudan)", Mansoura Engineering Journal, (MEJ), Vol. 37, No. 1, March 2012, C39 - C45.

[13] Sayed Mahgoub (2014), "Hydropower Studies for Sue MultiPurposes Dam", Hydraulics Research Institute (HRI), Delta Barrage, Egypt, Technical Report No. 269/2014 
[14] Sayed Mahgoub (2014), "Water Treatment Plant Studies on Sue River, Wau City, South Sudan", Hydraulics Research Institute (HRI), Delta Barrage, Egypt, Technical report No. $264 / 2014$

\section{Notation and Abbreviation}

\section{Symbols}

$A_{f}$ : Conveying cross-section $\quad\left[\mathrm{m}^{2}\right]$

$A_{t} \quad$ : Total cross-sectional area $\left[\mathrm{m}^{2}\right]$

C : Chézy coefficient $\left[\mathrm{m}^{1 / 2} / \mathrm{s}\right]$

$g$ : gravitational acceleration $\left[\mathrm{m} / \mathrm{s}^{2}\right]$

$h \quad:$ Water level relative to reference level $\quad[\mathrm{m}]$

$q_{\text {Lat }}:$ Lateral inflow per unit length $\quad\left[\mathrm{m}^{3} / \mathrm{m} / \mathrm{s}\right]$

Q : Discharge

$R \quad:$ Hydraulic radius (roughly equal to the water depth) $\quad[\mathrm{m}]$

$t \quad$ : Time

$W_{f}$ : Width of conveying cross- section at water surface $\quad$ [m]

$X \quad$ : Distance along the channel $[\mathrm{m}]$

$\alpha_{B}:$ Boussinesq coefficient

$\begin{array}{rlr}\mathrm{n}_{\mathrm{m}} & : \text { Manning's Roughness } & {[-]} \\ \mathrm{i} & \quad \text { Index }\end{array}$

Abbreviations

\begin{tabular}{|c|c|}
\hline EFTCA & $\begin{array}{l}\text { : Egyptian Fund for Technical Cooperation with } \\
\text { Africa }\end{array}$ \\
\hline GIS & : Geographical Information System \\
\hline MW & : Megawatt \\
\hline $\mathrm{msl}$ & : Mean Sea Level \\
\hline $\mathrm{m}$ & : Meter \\
\hline $\mathrm{S}$ & : Second \\
\hline M & : Million \\
\hline HRI & : Hydraulics Research Institute \\
\hline DEM & : Digital Elevation Model \\
\hline $1-\mathrm{D}$ & : One - Dimensional \\
\hline $\mathrm{m}^{3} / \mathrm{s}$ & : Meter Cube per Second \\
\hline Max. & : Maximum \\
\hline Min. & : Minimum \\
\hline WB & : World Bank \\
\hline
\end{tabular}

